\title{
Without Moths or Bats, Cacti form Friendships with Bees: Reproductive Biology of the Queen of Night Selenicereus Setaceus (Cactaceae) in São Thomé Das Letras, Brazil
}

Paulo S.P. Sampaio ( $\sim$ pspsampaio@unisanta.br)

Universidade Santa Cecília

Odair J.G. de Almeida

São Paulo State University

\section{Research Article}

Keywords: Selenicereus setaceus, dragon-fruit crops, Pollination, Apis mellifera

Posted Date: July 26th, 2021

DOI: https://doi.org/10.21203/rs.3.rs-690841/v1

License: (a) (i) This work is licensed under a Creative Commons Attribution 4.0 International License. Read Full License 


\section{Abstract}

Epiphyte, hemiepiphyte and scandent cacti comprise about $10 \%$ of the total species of Cactaceae and are the least studied group in the family. Despite the close relationship of Selenicereus setaceus with the well-known and internationally traded pitahayas / dragon-fruit crops, researchers have only recently increased their study of this species. Selenicereus setaceus is the only species of the genus that occurs in the southern American continent; the genus has its center of diversity in Central America and Mexico. Experiments using exclusion methods were carried out to monitor reproductive success and determine which floral visitors were effective pollinators of $S$. setaceus in southeastern Brazil. Pollination treatments were carried out to determine the reproductive system of the species in addition to observations to unveil the phenology and quantify the volume and concentration of sugars of the nectar produced during anthesis. The Apis mellifera bee was the most frequent visitor and the main pollinator of the $S$. setaceus flowers. The studied population is self-compatible and fruits with manual or spontaneous self-pollination through physical contact between the anthers and the stigma lobes during flower closing. The nectar had an average sugar concentration of $28.3 \%$ and an average volume of $133 \mu$. Although the floral characteristics fit into the sphingophily and chiropterophily syndromes, natural pollination occurred mainly from daytime visitation by $A$. mellifera, which promotes both self-pollination and cross-pollination mainly during the flower closing period between 5:00 am and 10:00 am. In addition, spontaneous self-pollination also contributed to increasing the rate of fruiting, since visits by nocturnal pollinators were rare.

\section{Introduction}

From the 1438 species of the Cactaceae ${ }^{1}$, about 130 are epiphytic, facultative epiphytes, hemiepiphytes or climbing ${ }^{2,3}$, and they were traditionally divided into two tribes, Rhipsalideae (with species distributed mainly in South America) and Hylocereeae (most species in this tribe are from Central America) ${ }^{4}$.

In the Cactoideae tribe, growing habits have evolved independently, at least twice, from terrestrial columnar lineages in distinct geographical areas ${ }^{2}$.

The main characteristic of the Hylocereeae is their predominantly hemi-or holoepiphytic habit; no clear morphological synapomorphies can be reported for this group. The Hylocereeae contain terrestrial, scandent, hemiepiphytic and holoepiphytic species. Many of the species form aerial roots. The stems can be ribbed and spiny and succulent to various degrees or flattened and leaf-like. Flowers and floral syndromes are very diverse: there are very large, nocturnal flowers as well as bright red flowers, presumably bird-pollinated, and small, white flowers ${ }^{5}$.

The circumscription of the Hylocereeae historically assigned by Bauer ${ }^{6}$, including Hylocereceus (A. Berger) Britton \& Rose (15 species) and Selenicereus (A. Berger) Britton \& Rose (11 species), has been questioned in recent molecular phylogenetic studies $5,7,8$. Korotkova et al. ${ }^{5}$ analyzed 60 (from 63) species traditionally recognized as Hylocereeae, and the authors found that no genera were completely monophyletic, suggesting a circumscription, in which the former genus Hylocereus was transferred into Selenicereus.

Korotkova et al. ${ }^{5}$ presented several arguments to keep the name Hylocereus instead of Selenicereus, such as the consistency of the name "Hylocereus" in terms of circumscription. In contrast, the name "Selenicereus" has been a genus with no clear concept. There is also the economic rationale of maintaining Hylocereus due to the international market for its edible fruits (pitahaya in Latin America and Dragon Fruit in China). Hunt ${ }^{9}$ effectively published new Selenicereus combinations before Korotkova et al. ${ }^{5}$, so the name Selenicereus had priority over Hylocereus. Thus, Hunt ${ }^{9}$ transferred Hylocereus into Selenicereus, considering Hylocereus a synonym of Selenicereus.

The center of diversity for Selenicereus occurs in Mexico, Central and north of South Americas. Selenicereus setaceus (SalmDyck) Berger [ $\equiv$ Hylocereus setaceus (Salm-Dyck ex DC.) Ralf Bauer] is the unique species which occurs in the South America's Southern region (Brazil, Paraguay, Bolivia eastern, and Argentina Northeast) ${ }^{1,5,9,10}$. It may be terrestrial or epilithic, occurring over sandstone, gneiss or quartzite rocky outcrops, and frequently found in disturbed areas ${ }^{10-13}$. 
Selenicereus ("Selene"= goddess of the moon; "Cereus" referring to the nocturnal flowers), is characterized by scrambling, climbing or epiphytic plants that grow on trees or rocks (epilithic), sometimes forming large clumps. Stems are 2-12 ribbed, winged or angled, segmented, green or glaucous, producing aerial roots; spines short, bristly, hair-like or acicular, and rarely absent. Flowers are medium-sized to very large, 12-40x10-30cm, funnelform, nocturnal. Flower areoles have hair-spines, bristles, spines or scales. The tepal is usually white or yellow, pink, red or brown with numerous stamens in a continuous series or with a throat-circle. The style is thick. Fruits are globose, ovoid or oblong, fleshy, and usually red. Seeds are oval or broadly oval with a mucilage sheath present, covering the entire seed ${ }^{9}$.

The relationship between flowers and its visitors is mostly established by means of a floral reward. To be effective, this resource must satisfy at least one of the principal needs of the animals, i.e., feeding, reproduction, or shelter. Pollen, nectar, oil, gum, resin, and water are the main rewards for animals which visit the flowers ${ }^{14,15}$.

Cactus flowers show a wide variety of forms, sizes, colors, and structural features that are related to the evolutionary history of their lineages, and they have been visited by bees, hummingbirds, moths, hawkmoths, and bats ${ }^{16-19}$. Flowers, with their pollen and nectar, are important food resources for the pollinators ${ }^{19}$.

Hypanthium evolution allowed the development of a long floral tube, an important innovation to Cactoideae that provided a better diversity of floral visitors ${ }^{20}$. This floral morphology richness has provided a wide spectrum of pollination syndromes, in which bees are the most frequent pollinators and may be plesiomorphic in the Cactaceae, even though not all bee species are equally efficient for pollination ${ }^{16,18,20}$. Long-distance pollinators, such as bats, birds, and hawkmoths, play a key role in cactus family evolution promoting genetic variability ${ }^{19}$.

Reproductive biology studies are interesting to elucidate ecological networking among the taxa since successful pollination is a condition for reproduction and, therefore, for the temporal maintenance of the species in determinate localities ${ }^{21}$.

Studies related to the reproductive biology of Selenicereus $s^{22-26}$ are not abundant and the majority have an agronomical bias, focused on the production, quality and nutraceutical proprieties of the fruits ${ }^{27-45}$.

Despite several species marketed as pitahayas or dragon-fruits, such as Selenicereus undatus (Haw.) D.R. Hunt [三 Hylocereus undatus (Haw.) Britton \& Rose], Selenicereus monacanthus (Lem.) D.R.Hunt [三 Hylocereus monacanthus (Lem.) Britton \& Rose] and Selenicereus megalanthus (K.Schum. ex Vaupel) Moran [三 Hylocereus megalanthus (K. Schum. ex Vaupel) Ralf Bauer] $]^{5,9,31,36,46}$, all closely related to $S$. setaceus, there are not many studies focused on this species ${ }^{47-54}$.

The understanding of floral biology is of interesting for the genetic improvement and optimization of the crop production and may support the commercial use of the promising fruit of $S$. setaceus, the Brazilian savanna's pitahaya ${ }^{50,55}$. In this scope, this work aimed to investigate the reproductive biology of epiphytic/scandent cactus $S$. setaceus. Specifically, the study objective is to determine the reproductive phenology, anthesis, nectar production dynamics. We also aim to report floral visitors, effective pollinators, and the breeding system.

\section{Material And Methods}

\section{Study species and study area.}

The plant Selenicereus setaceus occurs as scandent/epiphytic on trees with adventitious roots along the stem (Fig. 1A), as a creeping plant on rocky outcrops (Fig. 1B), or in urban areas over stone walls (Fig. 1C). It has light green trigonous stems, rarely 4-5 ribed (young phase), and 70-400 x 2.5-6 cm. The outer perianth-segments of flowers are red-green. Inner segments are white and delicate, bissexual, lateral to subterminal, with one per areole, $28-34 \times 28-30 \mathrm{~cm}$ (Fig. 1D-G). Nocturnal anthesis lasts only one night. The pericarpel is green with small scales and areoles with felt and spiny, floral tube with large scales, stamens numerous (317-393). The mature fruit is red with areoles with spiny, with dried floral remnants (Fig. 1I). Young individuals have few cladodes that may reach $1 \mathrm{~m}$ long, but the oldest ones may reach $8 \mathrm{~m}$ long, covering an area of $75 \mathrm{~m}^{2}$ (Fig. 1A-B). 
We performed the fieldwork in São Thomé das Letras (MG), Brazil, the region with altitude ranged between 1.280 and $1.498 \mathrm{~m}$; and climate classified as Cwb (according to Köppen) with cold and dry winters and mild and humid summers. The annual average temperature is $22^{\circ} \mathrm{C}$ (from $18^{\circ} \mathrm{C}$ in the winter to $24^{\circ} \mathrm{C}$ in the summer), and the precipitation has an average of 1.264 $\mathrm{mm}$ per year ${ }^{56}$. The dry season occurs from April to September, while the rainy season is from October to March.

We search for wild individuals of $S$. setaceus in an area of $228 \mathrm{Km}^{2}$, and we found ten individuals $\left(21^{\circ} 43^{\prime} 16.51^{\prime \prime} \mathrm{S}\right.$ $21^{\circ} 43^{\prime} 30.28^{\prime \prime} \mathrm{S}$ and $44^{\circ} 58^{\prime} 54.96^{\prime \prime} \mathrm{W}-44^{\circ} 59^{\prime} 11.90^{\prime \prime} \mathrm{W}$ ). The plants occur in the "Antonio Rosa City Park" (the municipal unit for nature conservation) and its damping zone. The licenses for sample collecting were authorized by the Biodiversity Information and Authorization System/Chico Mendes Institute for Biodiversity Conservation/Federal Environment Ministry (MMA) - (SISBIO number 49102-1).

Vouchers have been deposited at the Santa Cecilia University Herbarium - HUSC (Selenicereus setaceus (Salm-Dyck) Berg; examined material: Sampaio, P.S.P.; 1670, 1676, 1597 and 1046; HUSC - identified by Dr Diego Rafael Gonzaga in the Botanic Garden of Rio de Janeiro Herbarium -RB). The experiments and the observations occurred from September/2017 to December/2019.

Anthesis. To describe the floral biology of anthesis, we recorded and took measurements every 60 minutes per plant, from the time of which the floral bud started to opening until the time of the flower closing, after anthesis. Two measurements were taken about the floral diameter: 1) the distance between the outermost perianth-segments; and 2) the distance between the innermost perianth-segments (Fig. 1F). The movement of the stamens in the androecium, stigma lobes, and tepals were also recorded. In addition, the fragrance, dehiscence of the anthers, and receptivity of the stigma were also observed and noted. A hand magnifier and portable lights were used to aid the observations.

Nectar dynamics. The volume and nectar sugar concentration were measured during anthesis. The volume of the nectar was verified using a Gilson single-channel micropipette (10 to $200 \mu \mathrm{l})$ and $500 \mu \mathrm{l}$ microcentrifuge tubes. The sugar concentration (water/water) in the sugar solution was assessed through an Atago hand refractometer ( 0 to $32 \% \mathrm{BRIX}$ ). All analyzes were performed in virgin flowers, previously bagged, that were dissected longitudinally (Fig. 1G-H) immediately before collecting and measuring the nectar solution. For the nectar dynamics study, one different bagged flower was analyzed every two hours in the S. setaceus population during the night $(\mathrm{n}=8)$.

Floral visitors and effective pollinator. Continuous visual observations were performed throughout the anthesis, from $04 \mathrm{pm}$ to 11 am, totaling 90 hours $^{57}$. Floral visitors were recorded using a Sony Lens $\mathrm{G}$ camera and a Bushnell Essential E2 camera trap to analyze their behavior, time and frequency of the visits, how they get the reward, and whether they touch the reproductive whorls ${ }^{25,58,59}$. Floral visitors were identified through photos, and when it was possible, one individual of each species was captured with an entomological mesh or forceps, and then stored in $70 \%$ ethanol.

Previous and informal observations noted, a distinct assemblage of diurnal bees visiting the flower prior to anthesis (before sunset when the floral bud starts to open, showing a little aperture), and after anthesis (after sunrise when the flower has already begun to wither). Thus, to investigate the effectiveness of the whole spectrum of visitors (day and night times), we conducted visitor exclusion experiments $25,59,60$ in which the floral buds were bagged with veil sacs before anthesis and following fruit development, and then we analyzed the seed set per mature fruits. For (1) nocturnal pollination $(n=8)$, the flowers were unbagged at $07 \mathrm{pm}$ and bagged again at 05am (same night). For (2) diurnal pollination ( $n=12)$, the flowers were unbagged (exposed to visitors) for two periods - from $4 \mathrm{pm}$ to $7 \mathrm{pm}$, and 05 am to the floral senescence. For (3) diurnal pollination -flower opening $(n=8)$ : the flowers were unbagged only during the beginning of floral opening, from $4 \mathrm{pm}$ to $7 \mathrm{pm}$, being bagged again at $7 \mathrm{pm}$. For (4) diurnal pollination - floral senescence $(n=8)$ : the flowers were unbagged to allow visitors after 05am until floral senescence. For $(5)$ natural pollination $(n=118)$ flowers were not bagged, only marked with colored tape to follow fruit development. After anthesis, young fruits were unbagged and marked with colored tape to follow fruit development, and seeds were counted.

Breeding system. To investigate the breeding system of the $S$. setaceus population, some treatments were designed, such as hand self-pollination, spontaneous self-pollination, and cross-pollination complying with local and national regulations, based 
on Casas et a ${ }^{60}$, Valiente-Banuet et al. ${ }^{25}$, and Rocha et al. ${ }^{59}$. Experiments were performed during anthesis, from $07 \mathrm{pm}$ to $9 \mathrm{pm}$. At this time flowers already had a large floral opening and the stigma lobes were separated and turgid. To isolate the flowers from visitors, the floral buds were bagged with veil bags.

We settled on three experiments. For ( 1 ) hand self-pollination $(n=5)$, floral buds were bagged and $2 \mathrm{~h}$ after the flowers opening, they were hand-pollinated using pollen obtained from the same flower by saturating the stigma with fresh pollen using a virgin paint brush and re-bagged again. For (2) spontaneous self-pollination $(n=6)$, flowers were kept bagged throughout anthesis. For (3) hand cross-pollination $(n=5)$, floral buds were bagged and $2 \mathrm{~h}$ after the flowers opening, they were hand pollinated, using a virgin paint brush with pollen collected from different individuals, at least $50 \mathrm{~m}$ far from each other, and then bagged again. The collected pollen grains were stored in plastic flasks, to proceed with hand pollination in the same night according to the protocol of Silva et al. ${ }^{52}$.

After anthesis, with the senescence of the perianth and androecium, veil sacs were removed and young fruits were marked with colored tape to follow fruit development. Fruits that reached the maturation stage were collected and their seeds were counted.

Self-incompatibility (ISI) and autogamy (AI) indexes were calculated for fruit production ${ }^{61}$. ISI was calculated by dividing the fruit/flower ratio of the hand self-pollination treatment by the fruit/flower ratio of the cross-pollination treatment. Al index, in turn, was calculated by dividing the fruit/flower ratio of spontaneous self-pollination by the fruit/flower ratio of cross-pollination. ISI and Al values over 0.2 indicate self-compatibility and autogamy, respectively ${ }^{61}$.

\section{Results}

Reproductive phenology, anthesis and nectar. The blooming period of $S$. setaceus starts (with the first floral buds) in the second half of August - beginning of September. The first flowers open in the end of September (beginning of spring), having their peak from October to November. Fructification lasts from November to Janeiro, with the peak from December to January. Figure 2 indicates the annual pattern of flowering/ fructification.

Each individual is able to produce dozens of flowers per season. However, flowering is gradual and continuous during the blooming period (October-December). We found on average four opened flowers per individual per night, but it varied from one to twelve.

The development of the flower, from a floral bud of $5 \mathrm{~mm}$, takes $41 \pm 0.30$ days (mean $\pm \mathrm{SE}, n=7$ ) (Fig. 3), and the time between anthesis and fruit maturation lasts $63 \pm 2.36$ days (mean $\pm S E, n=5$ ). The flower starts to open around 4 pm (Fig. 4), two hours before the sunset. It begins showing a two centimeters rounded aperture among the tepal (Fig. 6A). At this time, the stigma lobes are united vertically (Fig. 6K). After 6 pm, the opening movements accelerate (tepals moving faster), and it stops around 08:30 $\mathrm{pm}$, when the flower is totally opened, four hours later after initiation (Fig. 1D-E).

The opened flowers are $30 \pm 0.4 \mathrm{~cm}$ (mean $\pm \mathrm{SE}, n=15$ ) long, and $29 \pm 0.5 \mathrm{~cm}$ (mean $\pm \mathrm{SE}, n=15$ ) diameter between the external perianth-segments and $7.5 \pm 0.4 \mathrm{~cm}$ (mean $\pm \mathrm{SE}, n=15$ ) diameter between the internal perianth-segments. That is, the visitors find an "entrance" of $7.5 \mathrm{~cm}$ to access and collect the floral rewards (Fig. $1 \mathrm{D}$ ). The floral scent is sweet and intense (to human sense), and is apparently produced by the white internal perianth-segments. The anthers release the pollen grains after $06 \mathrm{pm}$, through longitudinal slits. The androecium has about 317-393 stamens that produce vast amounts of pollen grains that fall down, accumulating on the internal surface of the tepals. The receptive stigma is opened, with turgid and shiny lobes, at this time, away from each other.

There is a temporary hercogamy in the flower, due to the position of the stigma far from the stamens (Fig. $6 \mathrm{~K}$ ), that changes later.

The flowers remain opened at $04 \mathrm{am}$, and then the stigma lobes start to lose their turgidity, becoming flaccid and dropping down. By the end of anthesis, the stigma lobes are in contact with the opened anthers (Fig. 6L). Thus, the spatial difference 
between stigma and anthers lasts only about eight hours. Along with the sunrise, the tepals begin to move into the center of the flower, starting the closing movement, that lasts until 10am (this can stretch to 11 am on cloudy and cooler days).

The nectar is produced and secreted by the floral nectary, and accumulates in the nectariferous chamber, inside the floral tube (Fig. 1G-H). The volume found in the nectar chamber of virgin flowers was $133 \pm 18 \mu \mathrm{l}$ (mean $\pm \mathrm{SE}$, $n=8$ ), with $28.3 \pm 0,8 \%$ (mean $\pm \mathrm{SE}, \mathrm{n}=8$ ) nectar sugar concentration. According to the nectar dynamics analysis (Fig. 5), the nectar volume increases during the anthesis, starting with $50 \mu \mathrm{l}$ at $06 \mathrm{pm}, 160 \mu \mathrm{l}$ at $11 \mathrm{pm}$, and $235 \mu \mathrm{l}$ at 05am. Interestingly, we noted the plant reabsorbed the nectar during the flower senescence, because at 09am the amount of nectar was about $110 \mu \mathrm{l}$ (Fig. 5).

Floral visitors. We recorded only six species visiting the flower (Table 1; Fig 6A-J) in 90 hours of observations (48 hours at night from $7 \mathrm{pm}$ to $5 \mathrm{am}$ - and 42 hours in the daytime - from $04 \mathrm{pm}$ to $7 \mathrm{pm}$, and from $05 \mathrm{am}$ to $11 \mathrm{am}$. The most frequent visitor was the honey bee Apis mellifera Linnaeus (Fig. 6A-D), that starts with few individuals around 4 pm (Fig. 7). The pre-anthesis flowers at this time had an opening of $1.5-2 \mathrm{~cm}$, and this is enough for a honey bee to enter the flowers and collect pollen grains from the opened anthers (Fig. 6A, D).

As time goes by, the opening in pre-anthesis increases, and the numbers of honey bees increase too (Fig. 6B; 7). There was recorded a second bee on the flower, in the beginning of anthesis, the meliponine bee Trigona spinipes Fabricius (Fig. 6E). Although the two bees compete for the same resource (pollen grains), A. mellifera dominated the area, not allowing T. spinipes to reach the flower. At sunset, the honeybees stopped collecting pollen grains. At this time, around $6 \mathrm{pm}$, the flowers still are not totally opened, and the stigma lobes are close to each other (Fig. 6K).

During the night, only one visit was recorded: the sphingidae hawkmoth Manduca rustica Fabricius at 06:30 pm - in the beginning of the anthesis, on a flower not totally opened (Fig. 6F). The hawkmoth landed on the flower, opened space among the stamens to get close to the floral tube entrance, access the nectar chamber, and collect nectar with its extensive proboscis. The visit lasted about 25 seconds. During the visit, the hawkmoth's body and wings touched the anthers and stigma, and lots of pollen grains stuck on the ventral part of its body.

Another eventual visitor found was the beetle Cyclocephala melanocephala Fabricius that was found walking on the internal surfaces of the perianth during the night to eat the fallen pollen grains, and to copulate. They may stay in the flower up to two days after anthesis (Fig. 6G).

At the beginning of the dawn, between 05 and 06 am, honey bees $A$. mellifera resumed harvesting pollen grains (Fig. 6C, 7). The flowers still had a $4 \mathrm{~cm}( \pm 1 \mathrm{~cm}, \mathrm{SE})$ opening between the internal perianth-segments. Honey bees landed on the flowers and walked over the anthers and stigma lobes, promoting self- and cross-pollination.

Honey bees have no morphological conditions to collect nectar in the nectar-chamber, so that, whenever the pollen resource has gone, the visits end as well. This occurs around 09-10 am (Fig. 7). At this time the perianth is withered and almost totally closed. No visits of the bees $T$. spinipes were recorded during this time.

The ant Camponotus rufipes Fabricius patrols the exterior of floral buds, flowers and immature fruits, both in day and night. The ants search for the nectar secreted by nectaries located at the areoles on the surface of the scales of the pericarpel and floral tube (Fig. 6 I-J).

Visits of the native cockroach from the family Ectobiidae were observed on a perianth-segment twice, entering and leaving the flowers in the morning, after the anthesis (Fig. 6H). However, it did not collect any resource or have any relationship with other visitors (honey bees, in this case).

Breeding system and effective pollinator. The results from the breeding system experiments are listed in Table 2. The hand selfpollinated flowers had $100 \%$ fruit set. The spontaneous self-pollination had $66.7 \%$ fruit set. The hand cross-pollinated flowers had $100 \%$ fruit set. The control group (natural pollination) showed $89.8 \%$ of fruit set. There was no fruit production via apomixis (flower with bagged stigma). 
The self-incompatibility index (ISI) found was 1 , and the autogamy index (AI) was 0.66 . That is, $S$. setaceus is self-compatible and fruit through self-pollination.

Regarding the treatments of temporal exclusion of the floral visitors (Table 2), the flowers exposed to diurnal visitors (04 $07 \mathrm{pm}$, and $05-11 \mathrm{am})$, had 100\% fruit set. The flowers exposed during the night (7 pm - $05 \mathrm{am})$ had 50\% fruit set. The control group (natural pollination) had $89.8 \%$ fruit set. In the treatments where the diurnal exposition of the flowers was split in two, we had $62.5 \%$ of fruit production for the flowers exposed to visitors from 04 to $07 \mathrm{pm}$; and $87.5 \%$ fruit set for the flowers that were exposed from 05 to $11 \mathrm{am}$.

Related to the number of seeds per fruit in the different treatments, we observed less seed production in fruits from spontaneous/hand self-pollination, 262/329 seeds, and more seed production in the control groups (natural pollination) - 658 seeds (Table 2).

\section{Discussion}

Selenicereus undatus is by far one of the most used plants to produce pitahaya as crop worldwide. The blooming of Selenicereus spp. normally occurs during summer when temperatures are higher and the day-time is longer ${ }^{22,26,34,48}$. It takes about 20 days to develop flowers, plus 35 days to fruit following anthesis $22,24,40,34$. In our results, S. setaceus took 41 days to develop flowers, plus 63 days to fruit production, i.e., twice as long to produce fruit. This may be a limiting factor in terms of fruit production as crop, when compared to $S$. undatus $22,24,40,34$.

The duration of anthesis seems to be consistent among the queen-of-the-night cacti. Selenicereus setaceus has anthesis during 18 hours (with the floral senescence about 5 hours after the sunrise). The same anthesis period was reported for other pitahayas, as S. undatus ${ }^{24,25}$, and S. megalanthus, S. monacanthus, S. undatus and S. costaricensis (F.A.C. Weber) S. Arias \& N. Korotkova ${ }^{26}$.

The high amount $(133 \mu \mathrm{l})$ of diluted nectar $(28 \% \mathrm{BRIX})$ produced by the $S$. setaceus flowers in natural environments was already recorded for this species in plants cultivated in a greenhouse, by Almeida et al. ${ }^{47}$, that found $160 \mu$ of nectar with $28 \%$ BRIX. In addition, the pattern found by the authors was higher volume and lower sugar concentration in the large flowers of seven Hylocereeae species, than in the 14 smaller Rhipsalideae species analyzed.

The nectar is secreted with particular rhythms and can be reabsorbed during the life of the flower. The temporal patterns of secretion, cessation, and resorption, if any, define the dynamics of nectar production. This dynamic is generally linked to the foraging behavior of visiting animals. Visitor activity, along with the alteration of environmental parameters, are responsible for the amount of nectar found in a flower in a determinate period of time ${ }^{62}$. In $S$. setaceus we found a large nectar volume between 8:00 pm and 1:00 am, with a peak at 11:00 pm. The highest peak of production was just before sunrise at 5:00 am; which leads us to conclude that the expected visitors would have a greater intensity of visits in these periods of greater volume of nectar secretion. In addition, the highest peak, before sunrise, may be related to the last nectar feeding of night visitors.

These results contrast with observations on other Selenicereus species. Valiente-Banuet et al. ${ }^{25}$ and Muniz et al. ${ }^{24}$ did not find any nectar produced in flowers of $S$. undatus e $S$. monacanthus, cultivated in Mexico and Brazil; the only reward offered to the floral visitor was the pollen grains. According to Valiente-Banuet et al. ${ }^{25}$, the absence of nectar production in $S$. undatus was due to the long time that this species has been used as crop by the Mexican people, that may have increased the capacity of this plants to produce fruits via self-pollination.

Selenicereus setaceus has flowers with nectary located in the long and narrow floral tube, producing diluted nectar ${ }^{47}$. The androecium produces a huge amount of pollen grains. The nocturnal anthesis lasts only one night. The flowers are whitish, and terminal in the branches over the canopy. It let them highlighted in the landscape, contrasting with the vegetation and the dark sky, facilitating their localization by the floral visitors. All these features match with chiropterophily and, mainly, sphingophily pollination syndromes ${ }^{14-16,63-65}$. 
This was confirmed by the visit of the sphingidea M. rustica, recorded in this study. This hawkmoth has a long proboscis able to reach the nectar chamber and drink the nectar to supply its high energetic demand ${ }^{66,67}$. Other cacti species are already known as recipients of hawkmoth visits ${ }^{68,69,58}$. However, in three seasons of observation, we got only one sphingidae visit (Fig. 6F). In addition to that, during these three years of nocturnal observation, we found no bat visits at all. As said before, the morphological attributes of the $S$. setaceus flowers, along with the literature records ${ }^{47,58,68,69}$ led us to expect to see nocturnal visitors. However, we found only one single hawkmoth visit! No nectarivorous bat visits were observed in Cereus hildmannianus K. Schum. flowers ${ }^{68}$, even with the occurrence of the bat Anoura caudifer E. Geoffroy in the same geographic areas. The authors only found hawkmoths visiting the flowers. Bats may prefer to feed on flowers with shorter floral tubes.

Fruit production among the plants which had their flowers exposed for the nocturnal visitors (unbagged from $07 \mathrm{pm}$ to $05 \mathrm{am}$ ) reached a $50 \%$ pollination ratio (Table 2). Since the plants did fruit, there was some pollination (we assumed that it was by spontaneous self-pollination), though in a lower ratio than expected due to the lack of nocturnal visitors. On the other hand, the flowers exposed to the honey bees' visits, had $100 \%$ fruit set (Table 2 ).

Concerning the flowers visited by honey bees, $A$. mellifera lands on the flower, gets into the perianth (because the flower is not opened yet), and walks around collecting pollen grains, even touching the stigma. At this time, the bees have their bodies covered by pollen grains so they may promote both cross- and self-pollination on the flower (Fig. 6A-D). In all observed visits, the honey bees were unable to reach the nectary. Therefore, they do not collect nectar.

Other studies have reported $A$. mellifera collaborating to morning pollination, after anthesis, in several other cacti species with nocturnal anthesis, including species of epiphytic cacti of Selenicereus ${ }^{24-26}$, the creeping cactus Cereus fernambucensis Lem. ${ }^{69}$, and the terrestrial cacti Cereus hildmannianus K. Schum. ${ }^{68}$, Carnegiea gigantea (Engelm.) Britton \& Rose, Pachycereus pringlei (S. Watson) Britton \& Rose e Stenocereus thurberi (Engelm.) Buxb. ${ }^{70}$, Pilosocereus tuberculatus (Werderm.) Byles \& G.D. Rowley ${ }^{59}$, Echinopsis terscheckii (Parm.) Friedrich \& G.D. Rowley ${ }^{71}$, and Cipocereus crassisepalus (Buining \& Brederoo) Zappi \& N.P.Taylor ${ }^{72}$.

The scarcity or lack of nocturnal visitors may have driven these species to become generalists, expanding the range of pollinators, when plants keep their nocturnal flowers opened and receptive for more hours after sunrise. This time extension in anthesis may supply the seasonal variation in abundance, reliability and competition among the nocturnal visitors (bats and/or hawkmoth) since the diurnal pollinators are more effective and stable $e^{70}$.

The presence of beetles is not rare in cactus flowers, as those found in the flowers of the $S$. setaceus, and have already been reported by some authors ${ }^{68,73,58}$. Usually, this coleopterous remain in one unique flower, feeding on floral parts. They may eventually self-pollinate the flower, stimulating thignomasty of the stamens ${ }^{74}$, but in most cases, the beetles are nectar and/or pollen robbers ${ }^{18}$.

The ants Camponotus rufipes, that were found patrolling the external surface of the stem, floral buds, and even, on the flower, were seeking the nectar secreted by the scales, on the areoles located on the pericarpel and floral tube surfaces (Fig. 6I-J). Nectar secretory structures, non-related to the pollination, are common in the cactus family, as recorded in Lophocereus schottii (Engelm.) Britton \& Rose ${ }^{75}$, several epiphytic cacti from Hylocereeae and Rhipsalideae ${ }^{47,76}$, Acanthocereus tetragonus (L.) Hummelinck, Leptocereus paniculatus (Lam.) D.R. Hunt and L. weingartianus (Hartmann in Dams) Britton \& Rose ${ }^{77}$. According to the literature these nectaries are involved in a mutualistic ant-plant relationship, in which the ant protects plant tissues against herbivory and other damage, like fungi infection, and then receive nectar as a reward ${ }^{75,77-79}$.

All the $S$. setaceus flowers analyzed showed an interesting movement in the stigma lobes at the end of the anthesis. After 04 am, they started to become flaccid and down projected, even touching the anthers, getting in contact with the pollen grains (Fig. 6L). Because of this movement, the well noted hercogamy at the begging of the anthesis (Fig. 6K) did not last until the end of the anthesis. Despite this, the hercogamy recorded at the anthesis would fit well in the concept of approach hercogamy (discussed in Cardoso et al. ${ }^{80}$ ): it is not effective to avoid intrafloral sexual interference. Thus, the hercogamy, of the studied 
flowers of S. setaceus, seems to be temporal, or even, a pseudo-hercogamy. That would explain the ratio of $66.7 \%$ fruit production in spontaneous self-pollination treatments.

Regarding the breeding system of $S$. setaceus, our results showed that in the studied populations the plants are not dependent on cross-pollination because they are able to fruit through self-pollination (forced and spontaneous) (Table 2). In spite of this, we expected to see more nocturnal visitors, including bats! In three years of observations, not even a single bat visit was recorded, and only one hawkmoth visit was observed. The treatment of nocturnal pollination had a $50 \%$ fruit set. Due to the very low presence of nocturnal visitors, and the high capacity of self-pollination, we believe that self-pollination explains the $50 \%$ ratio of fructification found in the flowers that were exposed in the night time (07pm to 05am).

Our results make clear the importance of the shift around anthesis duration, mainly stigma receptivity, and the visits of the honey bees because all the treatments that exposed the flowers to bees had high fruit set: between $62 \%$ to $100 \%$ (Table 2). Honey bees, therefore, play an important role in the pollination system of $S$. setaceus, contradicting our expectations.

S. setaceus is self-compatible and fruits through spontaneous and forced self-pollination treatments, in the former case, due to the pseudo-hercogamy. Our results also support self-pollination driven by $A$. mellifera. Nevertheless, the breeding system of Selenicereus may be very flexible. For instance, $S$. undatus populations did not fruit through spontaneous self-pollination in Minas Gerais-Brazil ${ }^{41}$ and Israel ${ }^{26}$; in Mexico ${ }^{25}$ and in Ceará-Brazil ${ }^{24} 100 \%$ fructification was reported from self-pollination. Similar inconsistencies occur concerning the forced self-pollination in populations of $S$. undatus. Silva et al. ${ }^{52}$ and $\mathrm{Ha}$ et al. ${ }^{34}$ reported low fruit set ratios in plants studied in São Paulo-Brazil and Taiwan; Pushpakumara et al. ${ }^{81}$, Weiss et al. ${ }^{26}$, ValientBanuet et al. ${ }^{25}$ found high ratios.

Valiente-Banuet et al. ${ }^{25}$ hypothesized that the divergence of results found in different locations for the same species is due to the use of different clone lineages and the authors also highlighted that during the domestication process, some plant species may become self-compatible. Thus, as $S$. undatus has been used since ancient times by mankind, it is putative that the selfcompatibility has evolved during its domestication. It would explain the different capabilities to fruit and even the absence of nectar in some Mexican populations.

Our data showed that the natural pollination had high fruit set efficiency $(89.8 \%)$ in the populations of $S$. setaceus. While less than the diurnal, hand self-pollination and hand cross-pollination treatments (which had 100\%), are still high (Table 2).

On the other hand, when we looked at the seed production per fruit, the differences are significant among the treatments, as seen in Table 2. For example, the hand self-pollination treatment had $100 \%$ fruit set, but the mean value of seed produced per fruit was low (329 seeds), while natural pollination had high mean value of seed set per fruit (658). For the pitahaya $S$. undatus, distinct studies showed different responses for similar treatments. Valient-Banuet et al. ${ }^{25}$ found more seeds produced per fruit in the spontaneous self-pollination treatment (7.940), than in the natural pollination (5.393). In contrast, Menezes et al. ${ }^{41}$ recorded less seed set per fruit for spontaneous self-pollination (822), when compared to the natural pollination (1.298). It is worth noting that the difference in mean values of seed produced per fruit probably indicates that they have studied different varieties of $S$. undatus.

\section{Conclusion}

Despite any inconsistencies about $S$. undatus seed production in the literature, per our results, we believe that the combination of different ways of pollen transport may promote better-quality fruits (with more seed set) in the studied populations of $S$. setaceus. In the natural pollination treatment, the flowers were exposed to the self and cross-pollination driven by honey bees, the self and cross-pollination driven by nocturnal visitors (hawkmoths), and spontaneous self-pollination. Which might have contributed to a more effective ovule fertilization, hence more seeds developed.

Although the floral characteristics fit into the sphingophily and chiropterophily syndromes, natural pollination occurred mainly from daytime visitation by $A$. mellifera, which promotes both self-pollination and cross-pollination mainly during the flower 
closing period between 5:00 am and 10:00 am. In addition, spontaneous self-pollination also contributed to increasing the rate of fruiting, since visits by nocturnal pollinators were rare.

Our study shows that although the plants of $S$. setaceus may have high rates of fruit set through self-pollination, these fruits may have only half of the number of seeds compared to fruits produced via cross-pollination. This information may be of interest to produce $S$. setaceus fruits for crop purposes since for cacti, the number of seeds is related to the weight of the fruit. Therefore, efficient pollination in a commercial crop will ensure better fruit quality ${ }^{26}$.

However, the presence of nocturnal and/or diurnal pollinators is fundamental for the plant to produce better quality fruits, in terms of the number of seeds, and certainly, it improves fitness too. Nevertheless, studies concerning the germination rates and seedling establishment would be central to evaluate the quality of the fruits produced and the offspring. As well as the potential of the seedlings to establish in the environment.

\section{Declarations}

\section{Acknowledgements}

We thank to Dr. Christie Klimas for the critical review in the early versions of the manuscript. We also thank the Brazilian National Council for Scientific and Technological Development (CNPq - Process 423273/2018-3) and the São Paulo Research Foundation (FAPESP - Process 19634-3/2018) for research grants to the Senior Author (OJGA).

\section{Author Contributions}

All authors conceived the study and designed the experiments, P.S.P.S performed experiments, all authors analyzed the data and wrote the manuscript, O.J.G.A contributed to revisions of the manuscript.

\section{References}

1. Hunt D., Taylor N.\& Charles G. The New Cactus Lexicon. DH books, Milborne Port, UK: 373 pp. (2006).

2. Wallace R. S., Gibson A. C. Evolution and systematic. In: Nobel P.S. (Ed), Cacti, Biology and uses. University of California Press, London, UK: 1-21 (2002).

3. Barthlott W et al. Biogeography and biodiversity of cacti. Schumannia 7, Bonn, GER: 215pp. (2015).

4. Barthlott, W. \& Hunt, D.R. Cactaceae. In: Kubitzki. K. (Ed.). The families and genera of vascular plants. v.2. Springer-Verlag, Berlin: 161-197 (1993).

5. Korotkova N., Borsch T. \& Arias S. A phylogenetic framework for the Hylocereeae (Cactaceae) and implications for the circumscription of the genera. Phytotaxa 327, 1-46 (2017).

6. Bauer R. A synopsis of the tribe Hylocereeae F. Buxb. Cactaceae. Systematics Initiatives 17, 3-63 (2003).

7. Bárcenas, R.T., Yesson, C. \& Hawkins, A. Molecular systematics of the Cactaceae. Cladistics 27, 470-489 (2011).

8. Hernández-Hernández, T., et al. Phylogenetic relationships and evolution of growth form in Cactaceae (Caryophyllales, Eudicotyledoneae). American Journal of Botany 98: 44-61 (2011).

9. Hunt D. Selenicereus. Cactaceae Systematics Initiatives 36: 29-36 (2017).

10. Flora Do Brasil 2020. Jardim Botânico do Rio de Janeiro. http://floradobrasil.jbrj.gov.br (2021).

11. Taylor N. P. \& Zappi D. Cacti of Eastern Brazil. Royal Botanical Gardens, Kew, London, UK: 499 pp. (2004).

12. Gonzaga D.R., Peixoto A.L. \& Menini-Neto L. Patterns of richness and distribution of Cactaceae in the Serra da Mantiqueira, Southeast Brazil, and implications for its conservation. Acta Botanica Brasilica, 33, 1-9 (2019).

13. SPECIESLINK. (2021) http://www.splink.org.br (2021).

14. Faegri K \& Van Der Pijl L. The principles of pollination ecology. Pergamon Press, Paris, FR: 244 pp. (1979).

Page $10 / 18$ 
15. Agostini K., Lopes A.V. \& Machado I.C. Recursos florais. In: Rech A. R., Agostini K., Oliveira P. E., Machado I. C. (Eds), Biologia da polinização. Projeto Cultural, Rio de janeiro, BR: 129-150 (2014).

16. Grant V. \& Grant K.A. The pollination spectrum in the southwestern American cactus flora. Plant Systematics and Evolution, 133, 29-37 (1979).

17. Anderson E.F. The cactus family. Timber Press, Portland, Oregon, US: 777pp. (2001).

18. Pimienta-Barrios E. \& Castillo R.F. Reproductive biology. In: Nobel P.S. (Ed), Cacti, Biology and uses. University of California Press, London, UK: 75-90 (2002).

19. Cardoso W.C., Calvente A., Almeida O.J.G. \& Sakuragui C.M. Floral biology of cacti and ecological implications. In: Santos M.R. (Ed), Cacti ecology, conservation, uses and significance. Nova Science Publishers, New York, US: 57-78 (2019).

20. Schlumpberger B.O. A survey on pollination modes in cacti and a potential key innovation. In: Patiny S. (ed.), Evolution of plant pollinator relationships. Cambridge University Press, Cambridge, UK: 301-319 (2012).

21. Eggli U. \& Giorgetta M. Flowering phenology and observations on the pollination biology of south american cacti. 2. Cereus aethiops. Haseltonia, 21, 19-40 (2015).

22. Marques V.B., Moreira R.A., Ramos J.D., Araújo N.A. \& Silva F.O.R. Fenologia reprodutiva de pitaia vermelha no município de Lavras, MG. Ciência Rural, 41, 984-987 (2011).

23. Mizrahi Y., Mouyal J., Nerd A. \& Sitrit Y. Metaxenia in the Vine Cacti Hylocereus polyrhizus and Selenicereus spp. Annals of Botany, 93, 469-472 (2004).

24. Muniz J.P.O., Bomfım I.G.A., Corrêa M.C.M. \& Freitas B.M. Floral biology, pollination requirements and behavior of floral visitors in two species of pitaya. Revista Ciência Agronômica, 50, 640-649 (2019).

25. Valiente-Banuet A., Gally R.S., Arizmendi M.C. \& Casas A. Pollination biology of the hemiepiphytic cactus Hylocereus undatus in the Tehuacán Valley, Mexico. Journal of Arid Environments, 68, 1-8 (2007).

26. Weiss J., Nerd A. \& Mizrahi Y. Flowering behavior and pollination requirements in climbing cacti with fruit crop potential. HortScience, 29, 1487-1492 (1994).

27. Castillo-Martinez R., Livera-Munoz M. \& Marquez-Guzmán G.J. Caracterización morfológica y compatibilidad sexual de cinco genotipos de pitahaya (Hylocereus undatus). Agrociencia, 39, 183-194 (2005).

28. Choo W.S. \& Young W.K. Antioxidant properties of two species of Hylocereus fruits. Applied Science Research, 2, 418-425 (2011).

29. Correia D., Nascimento E.H.S. \& Morais J.P.S. Crescimento de mudas de Pitaya (Hylocereus polyrhizus) em diferentes substratos. Embrapa Agroindústria Tropical, Boletim de Pesquisa e Desenvolvimento, 115, 1-20 (2016).

30. Costa A.C., Ramos J.D., Menezes T.P., Laredo R.R. \& Duarte M.H. Quality of Pitaia fruits submitted to field bagging. Revista Brasileira de Fruticultura, 39, 1-5 (2017).

31. Cruz J.A.M. et al. Pitahaya (Hylocereus spp.) un recurso fitogenético con historia y futuro para el trópico seco mexicano. Cultivos Tropicales, 36, 67-76 (2015).

32. Dallos M.P., Tirado A., Gutiérrez Y.M., Fischer G. \& Riaño J.R. Pitahaya, Selenicereus megalanthus (K. Schum. ex Vaupel) Moran (Cactaceae). In: Dallos M.P., Matallana L.P., Tirado A. (Eds), Biotecnología aplicada al mejoramiento de los cultivos de frutales tropicales. Universidad Nacional de Colombia, Bogotá, CO: 105-135 (2010).

33. Elmarzugi et al. Phytochemical Properties and Health Benefits of Hylocereus undatus. Journal of Nanomedicine and Nanotechnology 1, 1-10 (2016).

34. Ha T.D., Oanh L.T. \& Yen C.R. Flowering Phenology and Mating System of a red skin pitaya (Hylocereus spp.) germplasm collection in Taiwan. Asian Journal of Advances in Agricultural Research 7, 1-8 (2018).

35. Junqueira K. P. et al. Variabilidade genética de acessos de pitaya com diferentes níveis de produção por meio de marcadores RAPD. Revista Brasileira de Fruticultura 32, 840-846 (2010a).

36. Le Bellec F., Vaillant F. \& Imbert E. Pitahaya (Hylocereus ssp.) a new fruit crop, a market with future. Fruits 61, 237-250 (2006). 
37. Lichtenzveig J., Abbo S., Nerd A., Tel-Zur N. \& Mizrahi Y. Cytology and mating systems in the climbing cacti Hylocereus and Selenicereus. American Journal of Botany 87, 1058-1065 (2000).

38. Luo H., Cai Y., Liu T. \& Yang S. Chemical composition and in vitro evaluation of the cytotoxic and antioxidant activities of supercritical carbon dioxide extracts of pitaya (dragon fruit) peel. Chemistry Central Journal 8, 1-7 (2014).

39. Martínez R.C. Aprovechamiento de La pitahaya: bondades y problemáticas. Caos Conciencia 1, 13-18 (2006).

40. Menezes T. P. et al. Características físicas e físico-químicas de pitaia vermelha durante a maturação. Semina: Ciências Agrárias 36, 631-644 (2015b).

41. Menezes T. P., Ramos J.D., Bruzi A. T., Costa A. C. \& Ramos P. S. Autopolinização e qualidade de fruto em pitaia vermelha (Hylocereus undatus). Magistra 27, 386-393 (2015a).

42. Nunes E.N. et al. Pitaia (Hylocereus sp.): uma revisão para o Brasil. Gaia Scientia 8, 90-98 (2014).

43. Ramli N.S., Brown L., Ismail P. \& Rahmat A. Effects of red pitaya juice supplementation on cardiovascular and hepatic changes in high-carbohydrate, high-fat diet-induced metabolic syndrome rats. BMC Complementary and Alternative Medicine 14, 189-199 (2014).

44. Vaillant F., Perez A., Davila I., Dornier M. \& Reynes M. Colorant and antioxidant properties of red-purple pitahaya (Hylocereus sp.). Fruits 60, 3-12 (2015).

45. Wichienchot S., Jatupornpipat M. \& Rastall R.A. Oligosaccharides of pitaya (dragon fruit) flesh and their prebiotic properties. Food chemistry 120, 850-857 (2010).

46. Hunt D. Cites Cactaceae checklist 3 ed. Royal Botanical Gardens, Kew, London, UK: 170 pp. (2016).

47. Almeida O.J.G., Cota-Sánchez J.H., \& Paoli A.A.S. The systematic significance of floral morphology, nectaries, and nectar concentration in epiphytic cacti of tribes Hylocereae and Rhipsalidae (Cactaceae). Perspectives in Plant Ecology, Evolution and Systematics 15, 255-268 (2013).

48. Junqueira K.P., Junqueira N.T.V., Ramos J.D. \& Pereira, A.V. Informações preliminares sobre uma espécie de pitaya do Cerrado. Embrapa Cerrados, Planaltina, Distrito Federal, BR: 18pp. (2002).

49. Junqueira K.P. et al. Diversidade genética de pitayas nativas do Cerrado com base em marcadores RAPD. Revista Brasileira de Fruticultura 32, 819-824 (2010b).

50. Lima C. A., Faleiro F.G., Junqueira N.T.V., Cohen K.O. \& Guimarães T.G. Características físico-químicas, polifenóis e flavonoides amarelos em frutos de espécies de pitaias comerciais e nativas do cerrado. Revista Brasileira de Fruticultura 35, 565-570 (2013a).

51. Lima C. A., Faleiro F.G. \& Junqueira N.T.V. Diversidade genética intra e interespecífica de pitaya com base nos frutos. Revista Brasileira de Fruticultura 35, 1066-1072 (2013b).

52. Silva A.C.C., Martins A.B.G. \& Cavallari L.L. Qualidade de frutos de pitaya em função da época de polinização, da fonte de pólen e da coloração da cobertura. Revista Brasileira de Fruticultura 33, 1162-1168 (2011).

53. Simão E., Socolowski F. \& Takaki M. The epiphytic cactaceae Hylocereus setaceus (Salm-Dick ex DC.) Ralf Bauer seed germination is controlled by light and temperature. Brazilian Archives of Biology and Technology 50, 655-662 (2007).

54. Simão E., Takaki M. \& Cardoso V.J.M. Germination response of Hylocereus setaceus (Salm-Dyck ex DC.) Ralf Bauer (Cactaceae) seeds to temperature and reduced water potentials. Brazilian Journal of Biology 70, 135-144 (2010).

55. Rech A.R. \& Westerkamp C. Biologia da polinização: uma síntese histórica. In: Rech A. R., Agostini K., Oliveira P. E., Machado I. C. (Eds), Biologia da polinização. Projeto Cultural, Rio de janeiro, BR: 27-44 (2014).

56. INMET. Instituto Nacional de Meteorologia. http://www.inmet.gov.br (2019).

57. Lehner P. N. Handbook of ethological methods. Garland STPM Press, New York, US: 403 pp. (1979).

58. Aona L.Y.S. et al. Pollination biology of three brazilian species of Micranthocereus Backeb. (Cereeae, Cactoideae) endemic to the "campos rupestres". Bradleya 24, 39-52 (2006).

59. Rocha E.A., Machado I.C. \& Zappi D.C. Floral biology of Pilocereus tuberculatus (Werderm.) Byles \& Rowley: a bat pollinated cactus endemic from the "Caatinga" in northeastern Brazil. Bradleya 25, 129-144 (2007). 
60. Casas A., Valiente-Banuet A., Rojas-Martínez A. \& Dávila, P. Reproductive biology and the process of domestication of the columnar cactus Stenocereus stellatus in Central Mexico. American Journal of Botany 86, 534-542 (1999).

61. Zapata T.R. \& Arroyo M.T.K. Plant reproductive ecology of a secondary decidous tropical forest in Venezuela. Biotropica 10, 221-230 (1978).

62. Pacini, E. \& Nepi, M. Nectar production and presentation. In: Nicolson S.W., Nepi M., Pacini E. (Eds), Nectaries and nectar. Springer, The Netherlands: 167-214 (2007).

63. Fleming T.H., Geiselman C. \& Kress W.J. The evolution of bat pollination: a phylogenetic perspective. Annals of Botany 104, 1017-1043 (2009).

64. Sazima M., Buzato S. \& Sazima I. Bat-pollinated flower assemblages and bat visitors at two Atlantic forest sites in Brazil. Annals of Botany 83, 705-712 (1999).

65. Fischer E., Araujo A.C. \& Gonçalves F. Polinização por vertebrados. In: Rech A. R., Agostini K., Oliveira P. E., Machado I. C. (Eds), Biologia da polinização. Projeto Cultural, Rio de janeiro, BR: 311-326 (2014).

66. Oliveira R., Duarte J.A., Rech A.R. \& Avila R.S. Polinização por lepidopteros. In: Rech A. R., Agostini K., Oliveira P. E., Machado I. C. (Eds), Biologia da polinização. Projeto Cultural, Rio de janeiro, BR: 235-258 (2014).

67. Nicolson S. W. Nectar consumers. In: Nicolson S.W., Nepi M., Pacini E. (Eds), Nectaries and nectar. Springer, The Netherlands: 289-342 (2007).

68. Silva W. R. \& Sazima M. Hawkmoth pollination in Cereus peruvianus, a columnar cactus from southeastern Brazil. Flora 190, 339-343 (1995).

69. Locatelli E. \& Machado I.C.S. Floral biology of Cereus fernambucensis: a sphingophilous cactus of resting. Bradleya 17, 8694 (1999).

70. Fleming, T.H. Pollination of Cacti in the Sonoran Desert: When closely related species vie for scarce resources, necessity is the mother of some pretty unusual evolutionary inventions. American Scientist 88, 432-439 (2000).

71. Ortega-Baes P., Saravia M., Suhring S., Godínez-Alvarez H. \& Zamar M. Reproductive biology of Echinopsis terscheckii (cactaceae): the role of nocturnal and diurnal pollinators. Plant Biology 13, 33-40 (2010).

72. Martins C., Oliveira R., Aguiar L.M.S. \& Antonini Y. Pollination biology of the endangered columnar cactus Cipocereus crassisepalus: a case of close relationship between plant and pollinator. Acta Botanica Brasilica 34, 177-184 (2019).

73. Locatelli E., Machado I.C.S. \& Medeiros P. Floral biology and pollination in Pilosocereus catingicola (Cactaceae) in Northeastern Brazil. Bradleya 15, 28-34 (1997).

74. Cota-Sánchez, J.H., Almeida O.J.G., Falconer, D. J., Choi, H. J. \& Bevan, L. Intriguing thigmonastic (sensitive) stamens in the Plains Prickly Pear Opuntia polyacantha (Cactaceae). Flora 208, 5-6 (2013).

75. Chamberlain S. A. \& Holland J.N. Density-mediated, context dependent consumer-resource interactions between ants and extrafloral nectar plants. Ecology 89, 1364-1374 (2008).

76. Almeida O.J.G., Paoli A.A.S. \& Cota-Sánchez J.H.C. A macro- and micromorphological survey of floral and extrafloral nectaries in the epiphytic cactus Rhipsalis teres (Cactoideae: Rhipsalideae). Flora 207, 119-125 (2012).

77. Mauseth J.D., Rebmann J.P. \& Machado S.R. Extrafloral nectaries in cacti. Cactus and Succulent Journa/ 88, 156-171 (2016).

78. Ness, J. H. A mutualism's indirect costs: the most aggressive plant bodyguards also deter pollinators. Oikos 113, 506-514 (2006).

79. Ruffner G. A. \& Clark W. D. Extrafloral nectar of Ferocactus acanthodes (Cactaceae): Composition and its importance to ants. American Journal of Botany 73, 185-189 (1986).

80. Cardoso J.C.F et al. Towards a unified terminology for angiosperm reproductive systems. Acta Botanica Brasilica 32, 329348 (2018).

81. Pushpakumara, D.N.G., Gunasena, H.P.M. \& Karyawasam, M. Flowering and fruiting phenology, pollination vectors and breeding system of dragon fruit (Hylocereus spp.). Sri Lankan Journal of Agricultural 42, 81-91 (2005). 


\section{Tables}

Table 1. Floral visitors recorded in Selenicereus setaceus flowers in São Thomé das Letras, Brazil.

\begin{tabular}{lll} 
ESPÉCIE & PERÍODO & RECURSO UTILIZADO \\
\hline Apis mellifera & Daytime & Pollen \\
\hline Trigona spinipes & Daytime & Pollen \\
\hline Manduca rustica & Nocturnal & Nectar \\
\hline Cyclocephala melanocephala & Nocturnal / Daytime & Pollen \\
\hline Camponotus rufipes & Daytime /nocturnal & Nectar \\
\hline Ectobiidae & Daytime &
\end{tabular}

Table 2. Fruit set and number of seeds ( \pm SE) per treatment of Selenicereus setaceus in São Thomé das Letras, Brazil.

\begin{tabular}{|lllllllll|}
\hline. & $\begin{array}{l}\text { Natural } \\
\text { pollination }\end{array}$ & $\begin{array}{l}\text { Diurnal } \\
\text { pollination }\end{array}$ & $\begin{array}{l}\text { Diurnal } \\
\text { pollination } \\
(4 \mathrm{pm}-7 \mathrm{pm})\end{array}$ & $\begin{array}{l}\text { Diurnal } \\
\text { pollination }\end{array}$ & $\begin{array}{l}\text { Nocturnal } \\
\text { pollination } \\
\text { (5am) }\end{array}$ & $\begin{array}{l}\text { Unmanipulated } \\
\text { self-pollination }\end{array}$ & $\begin{array}{l}\text { Hand self- } \\
\text { pollination }\end{array}$ & $\begin{array}{l}\text { Hand } \\
\text { cross- } \\
\text { pollination }\end{array}$ \\
\hline $\begin{array}{l}\text { Fruit } \\
\text { set } \\
(\%)\end{array}$ & 89.8 & 100 & 62.5 & 87.5 & 50 & 66.7 & 100 & 100 \\
\hline $\begin{array}{l}\text { Seeds } \\
\text { per } \\
\text { fruit }\end{array}$ & $(n=118)$ & $(n=12)$ & $(n=8)$ & $(n=8)$ & $(n=8)$ & $(n=6)$ & $(n=5)$ & $(n=5)$ \\
\hline
\end{tabular}

$n=$ Number of flowers used for each treatment in this study.

\section{Figures}



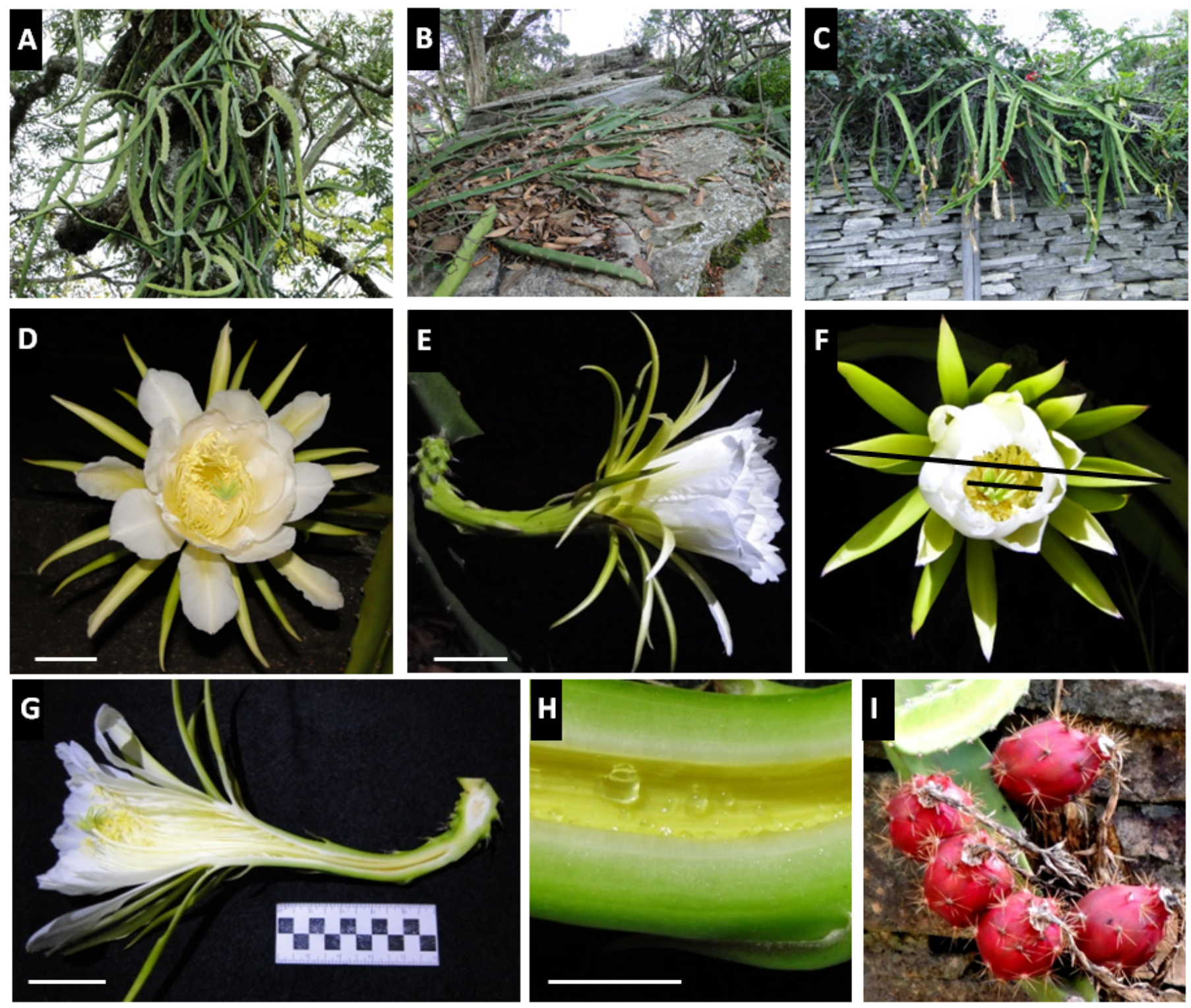

Figure 1

Growth forms of Selenicereus setaceus (A-C). A: Scandent plant climbing on an 8 meter's tree (Ceiba speciosa (A.St.-Hil.) Ravenna) with pendant stems. B: Creeping plant on a rocky outcrop. C: Scandent plant growing on cracks of stone walls (quartzite) with pendant stems in an urban area. D-E: Anthesis flower in frontal and lateral views at 8:43 pm. F: Anthesis flower at $19 \mathrm{~h} 11$ showing the two measurements about the floral diameter: distance between the outermost perianth-segments (bigger bar) and distance between the innermost perianth-segments (small bar). G: Flower in longitudinal section. H: Detail of the floral tube, showing the nectar chamber with nectar drops. I: Mature fruits (picture from Erich Sattelmayer). Scale bars: $5 \mathrm{~cm}(D, E, G)$, $2 \mathrm{~cm}(\mathrm{H})$.

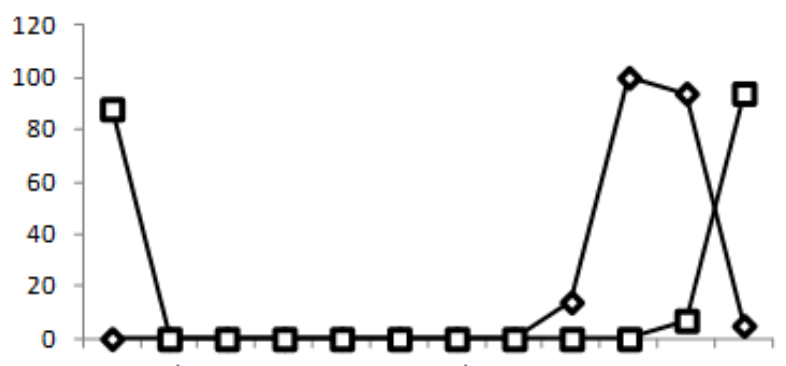

Jan Feb Mar Apr May Jun Jul Aug Sep Oct Nov Dec 
Figure 2

Reproductive phenology of Selenicereus setaceus exhibiting flower and fruit production in 2017.

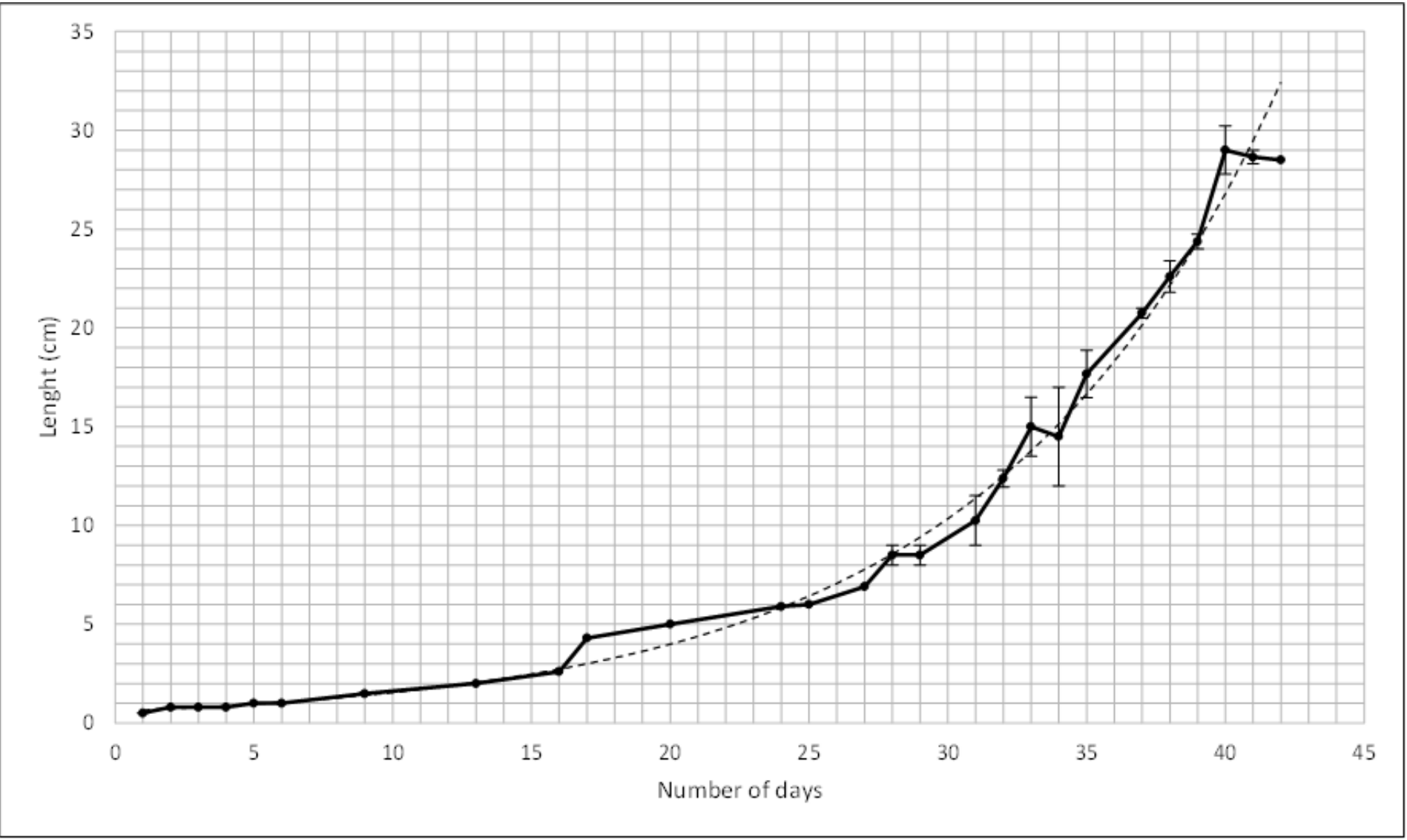

Figure 3

Floral bud development of Selenicereus setaceus from initiation at $0.5 \mathrm{~cm}$ length, up to the anthesis (mean $\pm S E ; n=7$ ). Continuous line (Mean), dashed line (exponential trend).

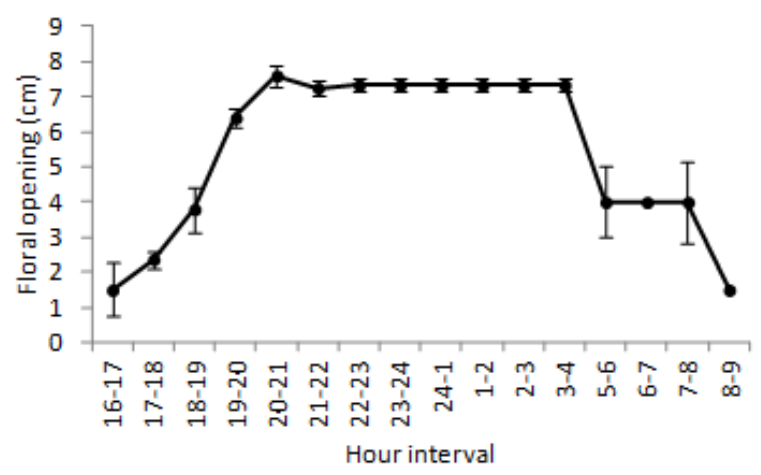

\section{Figure 4}

Floral opening during anthesis. Measurements were taken between the inner perianth-segments of the Selenicereus setaceus flower (mean $\pm S E ; n=11)$. 


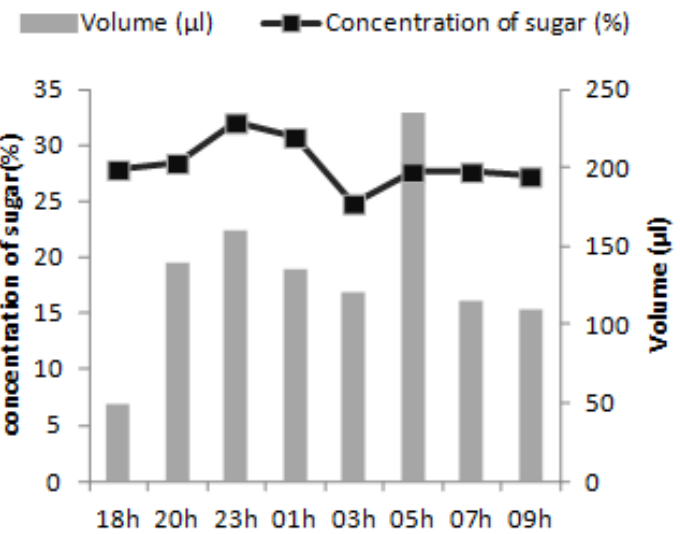

\section{Figure 5}

Nectar dynamics production during anthesis of the Selenicereus setaceus flower, nectar sugar concentration (\%) and volume $(\mu l)$.
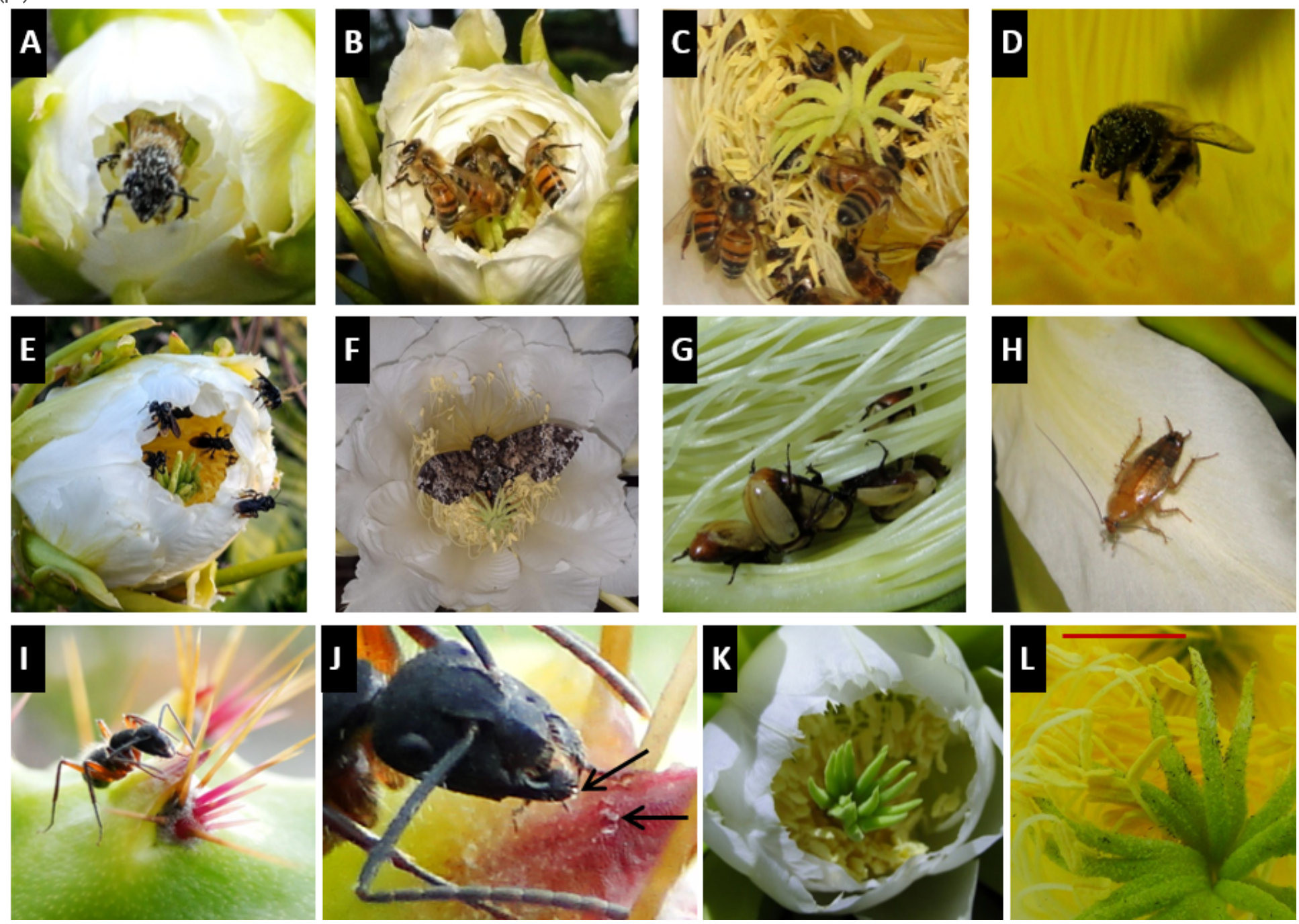

\section{Figure 6}

Floral visitors and stigma movement during anthesis of the Selenicereus setaceus. A: Flower, at 4:51 pm - beginning of anthesis - with Apis mellifera collecting pollen grains. B: Flower, at 6:05 pm - sunset - with several A. mellifera inside the nonopened flower. C: Highest number of A. mellifera inside the flower, at 5:12 am. D: Apis mellifera collecting pollen grains at 7:25 
am. E: Trigona spinipes collecting pollen grains at the beginning of flower anthesis, at 5:28 pm (picture: Erich Sattelmayer). F: Manduca rustica collecting nectar at 6:30 pm (picture: Adriana Riguetti). G: Cyclocephala melanocephala in post-anthesis flowers - two days after. $\mathrm{H}$ : Cockroach from the family Ectobiidae on a perianth-segment. I-J: Camponotus rufipes collecting nectar from a scale on the pericarpel. K: Stigma lobes in the begging of the anthesis, at 6:11 pm. L: Stigma lobes in the end of the anthesis, at 8:24 am - note the lobes touching the anthers. Scale bar: $1 \mathrm{~cm}(\mathrm{~L})$.

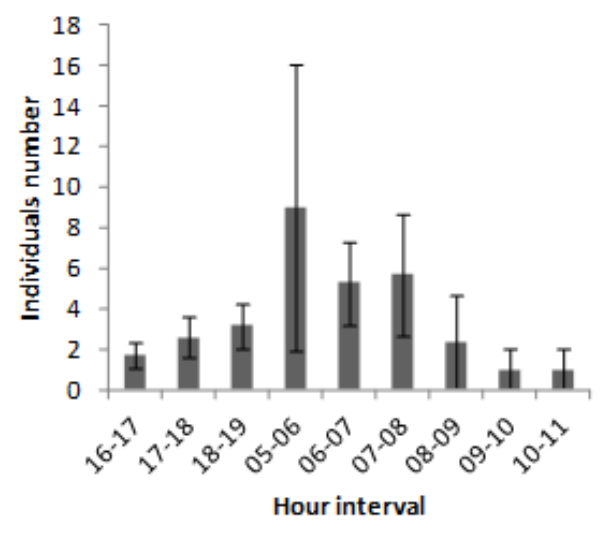

\section{Figure 7}

Maximum number of Apis mellifera individuals per flower of Selenicereus setaceus (mean $\pm S E ; n=8$ ). 